\title{
The Role of Farmers' Research Group to Promote Improved Technologies in Jimma and Illuababora Zones, Ethiopia
}

\author{
Berhanu Megerssa Beraka $^{1, *}$ and Getachew Weldemichael Abrha ${ }^{2}$ \\ ${ }^{1}$ Jimma University College of Agriculture and Veterinary Medicine, Jimma, Ethiopia \\ ${ }^{2}$ Ethiopian institute of Agricultural Research, Jimma Research Center, Jimma, Ethiopia
}

\begin{abstract}
Often driven by food security and market forces, farmers in Ethiopia have been innovating for centuries. However, innovation developments like FRGs have started to tap into the existing social systems only in the last few years. Similarly, there was no comprehensive study conducted on potato FRGs in the study areas. This paper is an output of research result, which analyzed the role of local innovations to promote improved potato technologies. Data was collected using semi-structured interview schedule involving 162 sample household heads. The result indicated that FRG participants were better involved in problem identification, prioritization, variety evaluation and dissemination than nonmembers were. Some of the major constraints identified from the assessment include weak linkage among stakeholders, high expectation for material incentive and poor participation of farmers in innovation system. The result also revealed that among fifteen independent variables tested, age of household heads, experience in potato farming, education level and extension service showed significant difference at $1 \%$ significant level whereas on-farm income, number of extension contact, farm distance and off-farm income showed significant difference at $10 \%$ significant level. However, the rest were insignificant. Hence, FRG approaches have assisted to improve the participation of clients in research and development activity. However, substantial support is required from stakeholders in order to improve linkage and broaden its scope.
\end{abstract}

Keywords: FRGs, Innovation, Potato, Stakeholders.

\section{INTRODUCTION}

\subsection{Introduce the Problem}

Potato (Solanum tuberosum L.) is the fastest growing staple food crop and source of cash income for smallholder farmers in Ethiopia. The German immigrant Wilhelm Schimper introduced it to Ethiopia in 1858. Despite its earliest introduction and highest potential than any African country, potato productivity in Ethiopia is too low $\left(7\right.$ ton $\left.\mathrm{ha}^{-1}\right)$ and its adoption is very gradual. Potato cultivation was also limited in the cooler highlands until its dissemination to other mid-altitudes at the end of nineteenth century (Medhin et al., 2001) [1]. Similarly seventy percent of the country's arable land is potentially suitable for potato cultivation (Haverkort et al., 2012; Kaburire and Ruvuga, 2006) [2, 3].

More than one million Ethiopian farmers are currently producing the crop where $80 \%$ of them are found in Oromiya and Amhara Regional States (Abera and Fasil, 2005) [4]. Ever since the adoption of various extension approaches in agricultural service delivery, research and extension has been working with different formal and informal Farmers' Groups (Steven and Richard, 2002) [5] which

*Address correspondence to this author at the Jimma University College of Agriculture and Veterinary Medicine, POB 307, Jimma, Ethiopia; Tel: +251-931-995050;

E-mails: berhanu.beraka@ju.edu.et, bermegber@gmail.com represented the building blocks of farmer organizations. Thus, empowerment of these groups and making their voices heard is very essential to understand their role in innovation and social capital involvement (Heemskerk and Wennink, 2004; Solomon and Engel, 1997) [6, 7].

Often driven by food security and market forces, farmers in Ethiopia have been innovating for centuries. Even though innovation is not a new phenomenon to the smallholder farmers in Ethiopia, the research and development support given to them by the scholars was very low. Thus, the experience is indeed in its infancy but only in the last few years' innovation development as FRGs has started to tap into the existing social system as a mean to adopt in research and development programs (Farrington and Martine, 1993; Kiflu and Berhanu, 2002) [8, 9].

With a general objective of evaluating the role of FRGs on potato technology production and transfer in the study areas, the research dealt with assessing the effect of FRGs in improving demand-driven and client oriented potato technology generation, identifying the role of farmers' research groups in promoting potato technologies and evaluating the prospects and constraints of working with FRGs.

\subsection{Importance of the Problem}

Despite the central contribution of local innovations in demand-driven and client oriented technology generation, there is no comprehensive study conducted on potato FRGs 
in the study areas. Similarly, there is no empirical evidence identified about their prospect and constraint towards incorporating participatory technology development and schemes. Besides, there is no systematically documented information on potato FRGs and their roles in enhancing client-oriented and demand-driven technology generation and adoption. This study was initiated to shed light on the contribution of FRG strategies in technology generation and adoption in the study sites.

\subsection{Relevant Scholarship}

By ranking fourth in volume of world's crop production following wheat, maize, and rice, potato is one of the most important food crops in the world, However, it ranks first among the root and tuber crops followed by cassava, sweet potatoes and yams Although it is remarkably adaptable crop, its expansion has been restricted by high temperatures in some regions of the world, For instance, in Ethiopia about $35 \%$ of the available agricultural land is situated in semi-arid regions of the country, where potato cultivation has not been practiced due to unfavorable high temperatures throughout the year. Thus, yield is greatly reduced by high temperatures, which inhibits tuber making. Thus, potato is well known "cool season" crop.

Farmers have several agronomic, economic, and cultural reasons to maintain and utilize crop genetic diversity. Among the agronomic reasons, yield stability, resistance to pests, and storability are in the forefront, whereas economic reasons embrace early maturity, production in hunger season, longevity in storage, market, and home economics. Cultural reasons such as consumption habits, beliefs, rituals, etc. have direct and/or indirect bearing on retaining or abandoning crop cultivars. The informal seed system hence plays a critical role in addressing these diverse preferences of smallscale farmers. Considering the global contribution of the informal seed system it is, therefore, indispensable and critical to understand the farmers' seed system for any crop and seed supply system reform to be realized.

\subsection{Hypotheses and Their Correspondence to Research Design}

Age (+/-): it refers to ages of the sample Household Heads in years. Older household heads participate less in the agricultural wage labor market, and are expected to be less active. In other ways, it is expected that younger farmers are more likely to be diversifiers of livelihood strategies than the older farmers. Thus, it is assumed that younger farmers have longer planning horizon and may result in investment of improved technologies. On the other hand, older farmers may have accumulated more knowledge, from their years of experience; thus, they are more reluctant to involve in local innovation processes.

Experience: Some empirical studies demonstrated that experience is a significant factor that influence farmers' decision. The finding of in Tanzania revealed that experiences in farming were positive and had significant association in adoption of RWH technology. This implies that long experience increases the probability of adopting improved agricultural technologies.

Education: increase the analytical ability of individuals to process information received from any source. Studies indicated that level of education increases farmers' adoption of improved agricultural technologies.

Education refers to the education level of $\mathrm{HH}$ in years. Education equips individuals with the necessary knowledge of how to make living. The education level of household head in particular and the education levels of households' members in general affect households' livelihood in various ways.

Family size: refers to the size of household members in Adult Equivalent (AE), which was expected to determine the households' choice of diversified livelihood strategies positively. Family size either determines the availability of family labor or, large family size demands large amount of production to feed its members, i.e., as family size increases, the demand for food increases. This means the larger the family size the higher the probability to participate in varied income sources.

\section{METHOD}

\subsection{Description of the Study Areas}

Jimma and Illuababora Zones of Oromiya Regional State are the prominent potato production areas in western Ethiopia. These zones are characterized by humid tropical climate with heavy annual rainfall, ranging from 1200-2000 mm, and a temperature range of $25-30^{\circ} \mathrm{C}$. Agriculture is the major economic activity mainly with small-scale mixed farming systems. Potato is now becoming the leading vegetable crop in the study area.

In the last two decades, different improved varieties of potato were introduced into Jimma and Illuababora Zones and among these Guasa, Jalene, Digemilign, and Tolcha were the most widely introduced ones.

\subsection{Participant (Subject) Characteristics}

Socio-economic, demographic, institutional, agronomic and postharvest activities were investigated between FRG members and non-members to see the role of local Innovations in promoting improved Technologies. To this effect, a combination of qualitative and quantitative data collection tools was employed to make use of the comparisons. Thus, pre-appraisal diagnostic survey was carried out in respective locations where informal discussion was held with farmers, frontline extension personnel, subject matter specialists and governmental and non-governmental offices. Trained researchers administer the interview schedules from Jimma Agricultural Research Center and pre-testing was duly made to curtail if questions are not measuring what is intended to measure. The data explored from informal surveys were triangulated with formal ones to understand real situations and to capture insights of why actors are doing what they formulate. 


\subsection{Sampling Procedure}

\subsubsection{Sample Size, Power and Precision}

A Multistage random and purposive sampling technique was used for the study to make comparisons between members and non-members. To this effect, Jimma and Illuababora Zones were purposively selected at first stage because of their prominence in catering potato FRGs in South Western Ethiopia. Then, three districts (two from Jima and one from Illuababora Zones) were purposefully selected since the districts were the only intervention areas where potato Five Kebele $^{1}$ administrations i.e. three from Jimma and two from Illuababora Zones were selected with same technique. Then 130 potato-producing farmers were selected (65 farmers from FRG members and the rest 65 from non-participant farmers). However, to maintain gender disaggregation, $25 \%$ female household heads were purposively included to make the final sample size of 162 farmers.

\subsubsection{Measures and Covariates}

Data on demographic and socio-economic characteristics, institutional factors, socio-psychological and technical factors, linkage and partnership, benefits and opportunities, constraints and challenges of working through FRG, level of use of improved potato production package, variety adoption, seeding rate, fertilizer and fungicide application was collected from members and non-members by using semistructured interview schedules. Similarly, data on household demographics, education and employment and social interactions was collected to uncover if membership to FRGs do affect technology generation or not. Similarly, 28 key informant interviews and 3 Focus Group Discussions were held for an in-depth understanding of some issues.

\subsubsection{Research Design}

The respondents were farmers, agricultural extension agents, NGOs and community leaders. Secondary data were also collected from reports, statistics, research papers, press clippings and journals. Statistical Package for Social Sciences (SPSS 16.0) software was used to analyze the information collected by semi-structured questionnaires and priority ranking was used to generate web diagrams and institutional networks. Rapid Appraisal of Agricultural knowledge Systems (RAAKS) tools were used to analyze task and impact analysis (Tool B5 and B1), and information source exercises (Tool B3/A). Moreover, linkage matrix tool (B4/A) and actors potential checklist (Tool $\mathrm{C} 2$ ) were used to examine the contribution of actors. Qualitative data from FGDs and group interviews were also analyzed through on spot analysis to avoid the apparent missing of relevant information.

\section{RESULTS}

\section{A. Demographic Characteristics}

\section{Age}

The mean age of the sample respondents was 41.57 years $(\mathrm{SD}=8.9)$ and majority of the respondents from FRG mem-

\footnotetext{
${ }^{1}$ Kebele is the lowest socio-political administrative strata in Ethiopia
}

bers were in the active labor force category (18-30 years) than non-members. Similarly significant relationship was observed $(\mathrm{t}=0.238, \mathrm{P}<0.01)$ between age of members and non-members which indicated that older age influenced the households to have a short planning horizon than young farmers as a result they are not willing to accept and to utilize new information due to their reluctance. Hence, youthfulness supported farmers' ability to integrate their indigenous knowledge with outsiders' through conducting informal experiments.

The result was in line with the observation of who reported that older household heads participated less than youngsters did; and thus where innovators find ways of building on existing knowledge to reflect new practices that have become integrated into the dynamic body of indigenous knowledge.

\section{Farm Experience}

The average years of farm experience for members and non-members were 8.45 and 3.29 years, respectively which showed that FRG members had significantly larger experience than non-members $(\mathrm{t}=8.56, \mathrm{P}<1 \%)$. The result indicated that members have better incorporated the piecemeal advice and blended with their own experience towards promoting local innovations and thereby provided a fast track succession in experimenting the technology. The result was in agreement with the findings of who indicated that farming experience assisted to evaluate and then prefer better agricultural technologies in participatory technology development.

\section{Education}

With significant difference between members and nonmembers $\left(\chi^{2}=34.288, p<0.01\right), 85 \%$ and $49 \%$ of members and non-members were literate, respectively. Thus, better educational status of members might have positively influenced the incorporation of local innovations to strengthen capacity of members and stimulats their storehouse of existing knowledge to conduct on-farm researches with relevant experience and inquiring minds.

The finding was congruent to the reports of Asgelil (2002) [10] that indicated positive relationship between education and role of local innovations, which assisted to gather momentum towards sustained production, against the going price.

\section{Family Size}

The mean family size of members (5.92) was a bit larger than the National average figure of 4.9 (CSA, 2008) [11], while that of non-members (4.84) was similar to the national average. Similarly, average number of economically active family members (15-30 years of age) was 2.74 for members and 2.23 for non-members. The mean difference was significant at less than 1 percent probability where larger family size assured availability of active labor force. The result is in agreement with the results of Chimdo et al. (2005) [12] who reported that family size played positive role in participation of local innovation where members made windfall profit. 
Table 1. Demographic and socio-economic characteristics of potato farmers in the study areas.

\begin{tabular}{|c|c|c|c|c|c|c|c|c|}
\hline Characteristics & Mean & SD & Mean & SD & Mean & SD & t-test & $P$ value \\
\hline Age of Household heads & 38.12 & 9.12 & 45.02 & 11.6 & 41.57 & 8.91 & -0.238 & $0.001 * * *$ \\
\hline Experience in potato farming (year) & 8.45 & 2.15 & 3.29 & 15.43 & 7.37 & 9.39 & 8.56 & $0.000 * * *$ \\
\hline Read and write & \multicolumn{2}{|c|}{36.12} & \multicolumn{2}{|c|}{32.14} & \multicolumn{2}{|c|}{34.13} & 34.288 & $0.000 * * *$ \\
\hline Primary school (1-4) & \multicolumn{2}{|c|}{23.27} & \multicolumn{2}{|c|}{18.81} & & & & \\
\hline Post primary (5-8) & \multicolumn{2}{|c|}{19.01} & \multicolumn{2}{|c|}{5.47} & & & & \\
\hline Family size (number) & \multicolumn{2}{|c|}{$\%$} & \multicolumn{2}{|c|}{$\%$} & \multicolumn{2}{|c|}{$\%$} & $x^{2}$ & $P$ value \\
\hline$<15$ years & \multicolumn{2}{|c|}{45.45} & \multicolumn{2}{|c|}{46.07} & \multicolumn{2}{|c|}{5.9} & 44.44 & 0.07 \\
\hline $15-64$ & \multicolumn{2}{|c|}{49.82} & \multicolumn{2}{|c|}{46.07} & & & & \\
\hline Above 65 & \multicolumn{2}{|c|}{4.73} & \multicolumn{2}{|c|}{7.85} & & & & \\
\hline \multicolumn{9}{|l|}{ Socio-economic characteristics } \\
\hline Livestock holding (TLUs) & 4.25 & 1.78 & 3.99 & 2.02 & 7.0 & 7.08 & 1.75 & 0.371 \\
\hline Off-farm income (USD) & 114.48 & 6.641 & 187.53 & 40.66 & 152.58 & 19.16 & 25.25 & $0.082 *$ \\
\hline
\end{tabular}

*** Significant at $1 \%$,** 5\%, and * $10 \%$ probability level

\section{B. Socio-economic Characteristics}

\section{Livestock Holding}

The livestock holding per household ranged from 0 to 9.12 TLU but there was no appreciable difference in average livestock holding between members and non-members $(\mathrm{SD}=7.08 ; \mathrm{t}=1.75)$ despite the importance of livestock as sources of draft power and cash income. Hence, the variable was not important for potato Participatory Technology Development (PTD) where agricultural labor-intensive practices were assisted by human labor than draft power.

\section{Participation in Off-Farm Activities}

The result indicated that $11.7 \%$ of respondents were involved in off-farm activities with average annual earnings of 114.48 USD $^{2}$. Similarly $35 \%$ of members and $59.84 \%$ of non-members were involved in off-farm activities to cover family expenses with statistical mean significance difference of $10 \%$ level; indicating that the resource poor farmers are usually engaged in off-farm activities to maximize shortterm benefits than investing on improved potato technologies.

${ }^{2} 1$ USD $=18.37$ Ethiopian Birr in January 2013
The result was in line with Sanginga et al. (2006) [13] who stated a positive relationship between off-farm income and stakeholder involvement with time as benefits of increased cooperation are realized.

\section{Participation in Non-Farm Activities}

According to $46.7 \%$ of the respondents, the average earning from non-farm activities was 154.71 USD. However, the mean difference was non-significant $(t=0.196)$ since both groups were involved in sale of labor as additional income source during the slack period. This source has thus improved the financial capacity of farmers to use improved technologies since households were not as such busy on onfarm activities given the short cycled nature of potato.

Critchley (1999) [14] also reported that poor rural nonfarm income and sustenance from a variety of sources like petty trade, micro-enterprise, brewing and casual labor are peripheral source of income to support small-scale farmers.

\section{On-Farm Activities}

With significant statistical difference $(\mathrm{t}=1.193, \mathrm{P}<5 \%)$, the mean annual on-farm income for FRG members and nonmembers was 1031.18 and 416.45 USD, respectively. This 
Table 2. Institutional factors that affected households access and use to cash and credit.

\begin{tabular}{|c|c|c|c|c|c|c|c|c|}
\hline \multirow[t]{2}{*}{ Access to Infrastructures } & \multicolumn{2}{|c|}{$\begin{array}{l}\text { FRG Members } \\
\qquad(\mathbf{N}=\mathbf{8 1})\end{array}$} & \multicolumn{2}{|c|}{$\begin{array}{l}\text { Non-Members } \\
\qquad(\mathbf{N}=\mathbf{8 1})\end{array}$} & \multicolumn{2}{|c|}{$\begin{array}{c}\text { Total } \\
(\mathrm{N}=162)\end{array}$} & \multirow[t]{2}{*}{ T-test } & \multirow[t]{2}{*}{$P$ value } \\
\hline & Mean & SD & Mean & SD & Mean & SD & & \\
\hline Access to credit (\%) & 74.10 & 10.21 & 28.05 & 8.25 & 51.575 & 9.23 & 0.624 & 0.855 \\
\hline Use of credit (\%) & 38.4 & 15.21 & 13.52 & 18.22 & 25.96 & 16.72 & 0.789 & $0.067 *$ \\
\hline Number of extension contact (Frequency) & 76.93 & 6.23 & 25.88 & 7.80 & 28.41 & 1.10 & 7.22 & $0.041 * *$ \\
\hline Farm Distance (km) & 4.21 & 17.51 & 6.44 & 7.73 & 5.83 & 6.92 & -8.13 & $0.039 * *$ \\
\hline Market Distance (km) & 7.96 & 16.57 & 6.01 & 14.04 & 7.37 & 1.79 & -7.99 & 0.991 \\
\hline Credit from Micro-finance (USD) & 165.56 & 12.02 & 72.12 & 5.86 & 118.84 & 13.32 & 732.99 & 0.401 \\
\hline Merchants (USD) & 296.28 & 21.51 & 989.08 & 80.37 & 192.07 & 21.53 & & \\
\hline Relatives (USD) & 915.38 & 66.47 & 169.5 & 13.77 & 581.06 & 65.14 & & \\
\hline
\end{tabular}

$* * *$ Significant at $1 \%, * * 5 \%$, and $* 10 \%$ probability level

result indicated on-farm activities were the best sources for members than non-members.

\section{Institutional Factors}

\section{Access to and Use of Credit Services}

The access to credit service in vicinity was by one fold less than its use. Hence, among $74.1 \%$ of members and $28.05 \%$ of non-members who had access to credit, only 38.4 $\%$ and $13.52 \%$ have benefited from the service, respectively. Regarding credit use, FRG members has an average of 165.56 USD, which is greater at least one fold than Nonmembers who does have only an average of 72.12 USD, respectively. In addition, this $65 \%$ of the credit was availed by Harbu Local Micro-finance Office; while the rest 35\% was provided by Oromiya Micro-finance Office. Regarding threat of non-using resource, high interest rate and fear of crop failure risk were major reasons mentioned by nonbeneficiaries $(64.7 \%)$ which required local Government's intervention to avail the resource. Hence, the situation compelled to enclave the activity in narrow focus in terms of area of intervention often leaving little behind other than locally cultivated success. Thus, institutionalization should be availed to internalize the methodology into the existing system.

\section{Extension Service}

Participation of in extension service for non-members was $21.52 \%$. While that of Members were $73.15 \%$. Similarly, significant variation was observed between groups indicating that members were better in using information to incorporate local innovations into participatory technology development. Similarly, extension agents have stimulated the innovative process by building an alliance between farmers, extension workers and researchers through shared commitment and relationships. However, farmer-to-farmer extension was important to reach out to more farmers, disseminate findings from Participatory Technology Development activities and spread the process since farmers were best actors in the dissemination process where farmers learn from and listen to each other, and spread knowledge to others.

The result was similar to the findings of Freeman (2001) [15] who reported that improving extension service amended barriers of information flow, which promoted participation, and confidence of innovators.

\section{Market and Farm Distance}

The total average farm and market distance were $5.83 \mathrm{~km}$ and $7.37 \mathrm{~km}$ respectively away from the residence of household heads. The closeness of market center enables the farmers to supply the perishable products like potato to reach market on time. On the contrary, longer distance has resulted in rotting and reduced market value of the produce that adversely affected the role of local innovation. The improved infrastructures helped to improve physical access and information flow, which promoted participation and confidence in innovation system. However, there was no network for seed and ware potato market.

The result was in line with the findings of Agajie (2002) [16] who found a negative but significant relation of farm distance to adoption of the technology.

\section{Psychological Perception of Output Price}

The average output price of ware potato during slack season was 0.14 USD per $\mathrm{kg}$ at farm gate but the price increased to 0.19 USD during the off-season. However, there was no significant difference between members and non- 


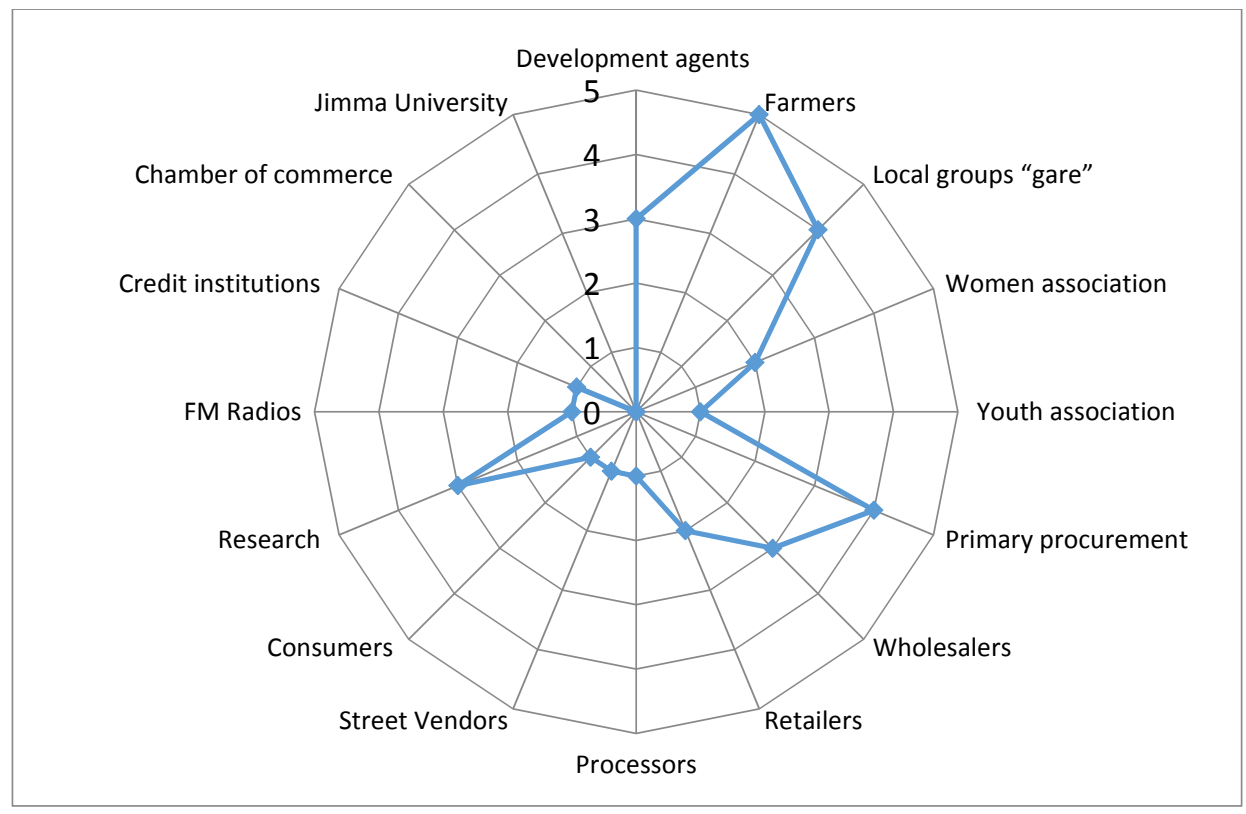

Fig. (1). Linkage among stakeholders in the study area Source: Own survey (October, 2010).

members produce price since the price variation was based on supply-demand factor, which include, storage conditions, product and product quality than categories. Due to the absence of organized market price information, producers lost alternatives to sell their product at whatever price given requesting induced innovation to address the spatial market availability.

\section{Knowledge of the Recommended Practices}

Knowledge of recommended practice was very important for farmers to practice it accordingly. The difference in knowledge level between members and non-members was significant at $1 \%$ probability level $(\mathrm{t}=2.793)$. Hence, regular contact and relationship with farmers have provided opportunities for researchers to learn about the farmers` real situations since $93 \%$ of FRG members have interacted with the stakeholders in regular meeting. Similarly, 50\% of FRG members reported that the forum helped to reorient research agenda and improve diffusion of technology while the rest reported that the interaction improved skill and knowledge of the stakes to realize real farmers' problems and the way to solve. Likewise all members reported that the approach improved their skill and knowledge to incorporate local innovation into technology generation. $73 \%$ of women household heads reported the mechanism has addressed their problem, which was previously skipped by the conventional research. Women contributed $37 \%$ of the total FRG member farmers in the study areas. This in turn contributed a lot in empowering rural women to participate in technology evaluation, generation and dissemination. It also provided opportunity to contribute their resources together in order to access rural credit.

\section{Functional Linkage and Partnership}

The linkage within farming households and their community groups (gare) was stronger than the conventional research and extension actors. But, the direct role of universities was totally absent as that of social Medias like FM radio stations and print Medias who were expected to play important role in the knowledge and information system (KIS). However, researchers (58\%) seldom took data generated from participatory works where farmers were taking the lead. Language used to communicate on statistical jargons with farmers was also reported to be a barrier (74\%). Similarly, $54 \%$ of researchers lack awareness about farmers' capacity to innovate and generate technologies; while $46 \%$ of researchers do not have operational guidelines to involve farmers in local technology development and innovation. For these reasons, they failed to accommodate interests of actors and give technical support to local innovations. The finding was in line with the report of IFPRI (2010)[17] ${ }^{3}$ which indicated the comfort zone to do research for researcher is behind a closed door (on station) and to work in isolation determining agenda determined from within 'research' and concentrating on experiments which produce readily publishable results. Similarly, many farmers believed that only literates and intellectual people, like extension workers, would bring something new and important to farmers.

\section{Challenges and Opportunities of FRG}

By combining different market actors, local associations and institutions (Fig. 2), FRG approach provided opportunity to interact with farmers and to economize time for technology development and adoption.

\section{Technology Development and Adaptation}

The average area allocated for potato production has increased from 0.24 ha per household to 0.35 ha per household

${ }^{3}$ It is smallest village level community group, voluntarily organized by collegial farmers but now given acknowledgement by local administration who use it for sociopolitical purpose 


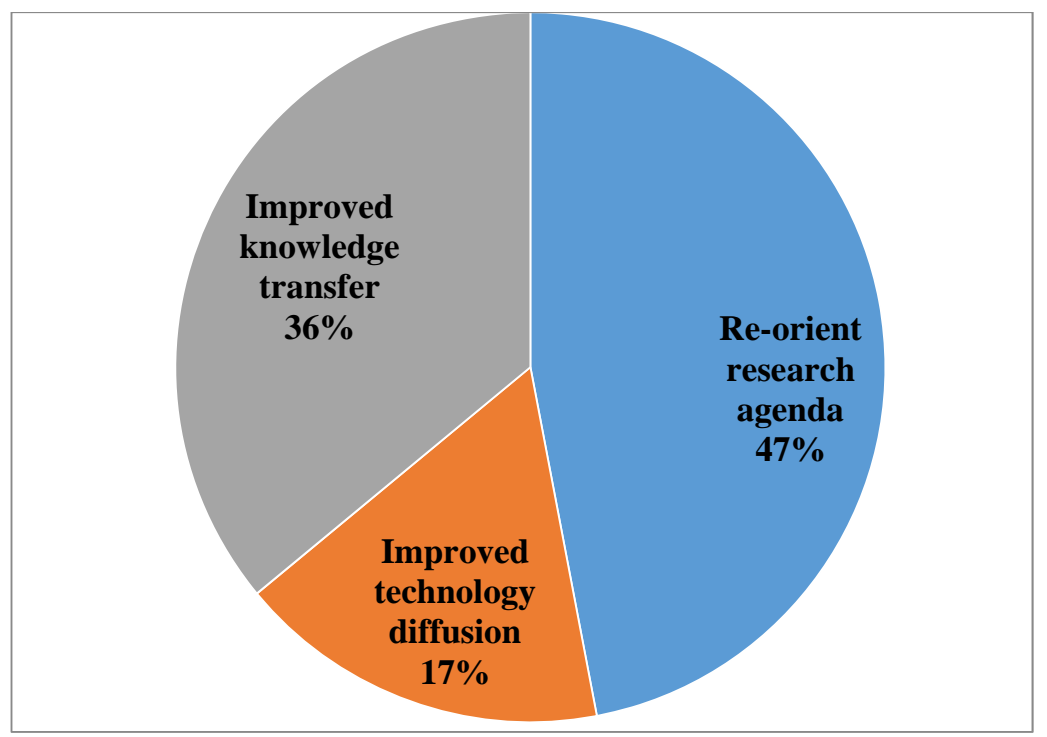

Fig. (2). Benefit and opportunities of working with FRGs (\%).

Table 3. Yield of improved varieties tested with FRGs.

\begin{tabular}{|c|c|}
\hline Variety & $\begin{array}{c}\text { Marketable Tuber Yield } \\
\left(\text { ton ha }^{-1}\right)\end{array}$ \\
\hline \hline Guasa & 28.96 \\
\hline Jalene & 22.24 \\
\hline Gudene & 14.69 \\
\hline Tolcha & 11.54 \\
\hline Local & 9.23 \\
\hline
\end{tabular}

in the last three years indicating the higher demand created for improved potato technology. Hence, improved technologies recommended by conventional research are now under use with some modifications through incorporation of local innovations. These include seed rate; fertilizer rate; date of planting, spacing between plants, and frequency of cultivation. $75 \%$ of potato FRG members have started to use improved agronomic practices like seed rate, fertilizer rate, frequency of cultivation and fungicide application.

\section{Variety Adaptation and Adoption}

Members have better adapted and adopted the introduced potato varieties than non-members. Thus, dramatic shift to production of variety "Guasa" was observed where $95 \%$ of the members opted to use it while the remaining (4.7\%) cultivated the other improved variety "Jalene" but none of them opted to use the local varieties. The first variety "Guasa" was selected due to its earliness (82.7\%); high yield advantage (78\%) and market demand $(41.3 \%)$. Despite great enthusiasm to try new things, non-members were constrained with resource limitations to take risks and carry out experiments with their meager resources. Hence, they were opted to stick to their traditional experiences. Thus, the participatory variety selection fostered the attraction of local knowledge to meet farmers' dynamic user demands and to choose their best bet variety, which they believe have the capacity to develop commercially. The result was in line with the report of IFPRI (2010) [18] which indicated that increasing quality and use of improved seeds dramatically increased Ethiopia's annual crop production.

\section{Seeding Rate}

Bulkiness of potato planting material was the major bottleneck for propagation. Similarly, this made its dissemination expensive compared to other vegetables. Hence, members started to use $8000 \mathrm{~kg}$ of potato tuber seed for one hectare of land while non-members used $12000 \mathrm{~kg}$ of potato tuber seed which is $50 \%$ more the seed used by members. The difference in seed rate was significant at 5 percent $(t=1.145)$ where FRGs members used smaller seed rate than non-members. Hence, iterative Innovation Platform provided opportunity to members to improve their production and address both quantity and quality of potato production that could meet market demands.

\section{Fertilizer Application Rate}

The mean fertilizer rate applied by sampled growers was $545.8 \mathrm{~kg}$ hectare-1. However, the rate of application signifi- 


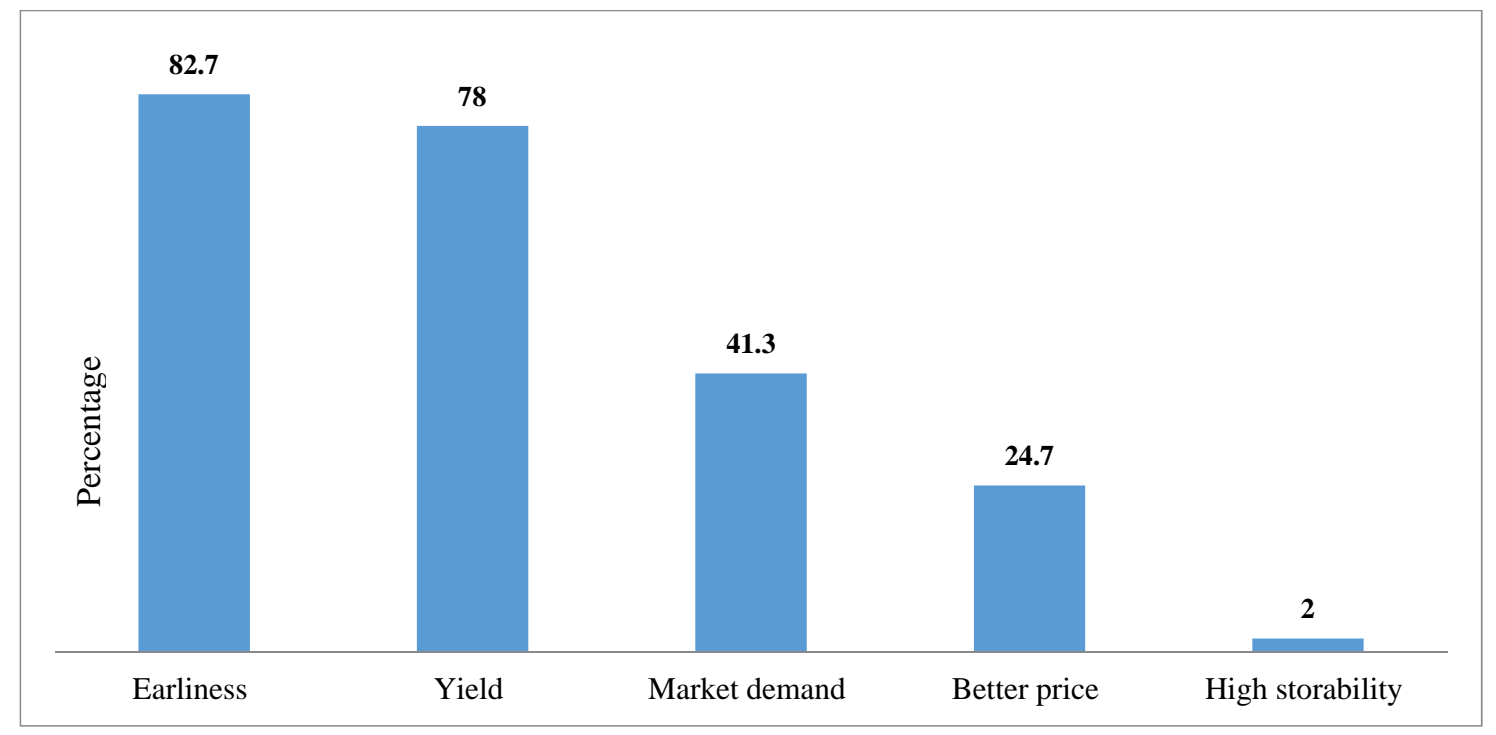

Fig (3). Farmers' preference of attribute of red variety in percent.

cantly varied among sample respondents $(\mathrm{P}<0.05)$. As supplement of the recommended inorganic fertilizer, the average amount of farmyard manure applied by members was 0.5 -ton $\mathrm{ha}^{-1}$, but the amount used by non-members was 0.18 -ton $\mathrm{ha}^{-1}$. However, provision of inputs for free had affected farmers' participation where they tend to show limited interest in research without it.

\section{Seed Potato Storage Methods}

Keeping potato tubers in the soil un-harvested (postponed harvesting), storing in local granary, storing on bed-like structures and storing on floor were respectively practiced by $18 \%, 24 \%, 27 \%$ and $31 \%$ of FGR non-members; while $78 \%$ of FRG members have adopted to store potato under diffused-light storage (DLS). Thus, storage pests are now major post-harvest problems to $83 \%$ of non-members and $12 \%$ of members of potato FRG groups.

The finding was similar to the report of Adane et al. (2010) [19] which indicated that postponed harvesting was common for ware potatoes in the highland and northwestern areas of Ethiopia to extend piece-meal consumption while seeking for a better price. According to the authors, tubers can be kept up to four months without major quality loss in the cooler highlands. This storage method is used to store seed potatoes.

\section{Fungicide Application}

Late blight of potato was the critical disease in ware potato production where its incidence and severity varied from season to season, and variety to variety. Though the fungicides, Ridomil or Mancozeb were recommended by the conventional research as last option to control the disease, FRG members have selected the best-bet resistant and adaptable variety, "guasa" among the previously recommended varieties.

\section{Potato Production Methods}

FRG members used narrower spacing for seed potato but wider for ware potato. However, there was no separate plot and management for ware and seed potato production among non-members where potato tubers were conventionally sorted into ware and seed after harvest. For non-members seed potato was usually considered as by-product of ware potato.

\section{Potato Diseases}

Late blight (Phytophthora infestans (Mont.) was common in all respondents' plots but the intensity was fierce in nonmembers farms that seldom used improved varieties of potato. As a result, these farmers were compelled to shift the production season from the long rainy season to winter. However, the disease did not affect members who used improved varieties.

The result was in line with the observation by Bekele and Eshetu (2008) [20] who reported that potato growers in Ethiopia usually produce potato in off-season despite the high potential yield in longer rainy season.

\section{DISCUSSION}

As hypothesized earlier, youthfulness had supported farmers' ability to integrate their indigenous knowledge for local innovations; since older ages had influenced the households to have a short planning horizon than young farmers. As a result, older farmers were not willing to accept and utilize new information due to reluctance. Similarly, FRG members had better access to use extension service than nonmembers, which indicated the better tendency of the members to integrate the piecemeal extension advice, with their own experience towards promoting local innovations and succession in experimenting the technology.

The larger number of years spent in formal school by most FGR members had influenced the choice and access to promote local innovations in participatory potato technology development; and this was in line to the hypothesis set earlier. As an indicator of available and active farm labor, larger family size, with age between 15 and 50, had assisted to provide sufficient labor for farming; and this opportunity had given a room to adopt new technologies. 
With better possession of livestock by households of FRG members, which was actually measured by total number of livestock in Tropical Livestock Unit (TLU), have assisted to generate better income and thereby to access and utilize more information. FRG household members with better possession of livestock have generated more income from TLU, which was typically measured by the continuous variable referring to the total number of livestock in Tropical Livestock Unit (TLU). Thus, the opportunity assisted the members to afford expenses of new technologies and access and utilize more information regarding improved potato technological packages like: well adapted cultivars, agronomic practices, post-harvest technologies like: improved storage (Diffused Light Store (DLS), transportation and marketing facilities.

The better involvement of member in off-farm activities (income from farm unrelated activities) had amended the purchasing power of the households; and thereby to access agricultural inputs like fertilizers and improved potato tuber seeds. Off-farm income had therefore showed a positive relationship between households' non-farm income and new technologies and ideas. Similarly, FRG members who have better access to credit and the chance to search agricultural informations afforded to buy and utilized improved potato technologies. This situation has also enabled the farmers to utilize new information than those having poor access to credit.

As market distance increased, farmers incurred more costs on transport, and spent additional time and energy. Thus, only those farmers in areas close to the market had better access to input at lower prices. As a result, the closeness of market and extension centers to FRG members had assisted for better adoption of improved potato technologies; and thereby positively influenced the use and accessibility of local innovations in participatory technology development. Hence, looking in to the benefits and challenges of the study results, the following points are forwarded as recommendation.

- The roles of FRG should be strengthened to address technology generation through participatory methodology using multidisciplinary team of researchers.

- The innovation system should be remedied through effective collective action of alleviating problems

- Research and extension organizations, community and farmer based organizations, and rural service providers should be strengthened for effective innovation

- Organizational collaboration needs to be strengthened to harness local knowledge

- Farmer-to-farmer dissemination should be fostered and scaled up with committed involvement of community-based organizations

- Farmer-driven orientation and the current extension service should be strengthened by inculcating PTD

\section{CONFLICT OF INTERESTS}

The authors confirm that this article content has no conflicts of interest.

\section{ACKNOWLEDGEMENTS}

The authors acknowledge researchers of Jimma Agricultural Center for cooperating and financing the project.

\section{REFERENCES}

[1] Medhin G, Giorgis W, Endale G, Kiflu B, Bekele K. Country profile on potato production and utilization: Ethiopia. Ethiopian Agricultural Research Organization (EARO), Holetta Agricultural Research Centre, National Potato Research Program, 2001.

[2] Haverkort A, Koesveld F, Schepers H, Wijnands J, Wustman R, Zhang X. Potato prospects for Ethiopia: on the road to value addition, Applied Plant Research, Wageningen UR Business Unit Arable Farming, Field production of Vegetables and Multifunctional, PPO no. 3250236012, Agriculture December 2012, The Netherlands Edelhertweg 1, Lelystad, The Netherlands, 2012.

[3] Kaburire L, Ruvuga S. Networking for agricultural innovation. The national network of farmers` group in Tanzania. (eds). Winnink B. and Heemskerk W, and Farmers Organization and Agricultural Innovation. Bulletin 374. Amasterdam, The Netherlands, 2006, 7985 .

[4] Abera D, Fasil K. An over view of participatory research experience in Ethiopia agricultural research system. Proceeding of workshop 20-21 October 2004, JARC, Jimma, Ethiopia, 2005, pp. 2327.

[5] Steven F, Richard C. Participatory on-farm technology testing: the suitability of different types of trial for different objective. In: Mauricio R. Bellon and Jane, R., (eds). Quantitative Analysis of Data from Participatory Method in plant Breeding. Mexico, DF: CIMMYT, 2002.

[6] Heemskerk W, Wennink B. Building Social Capital for Agricultural Innovation, Experiences with farmer groups in Sub-Saharan Africa, Bulletin 368. Royal Tropical Institute (KIT) - Amsterdam, 2004.

[7] Solomon M, Engel P. Networking for Innovation: Participatory Actor-Oriented Methodology. Royal Tropical Institute 1090 HA Amsterdam, KIT Press. The Netherlands, 1997.

[8] Farrington J, Martine A Farmer Participation in Agricultural Research: A review of concepts and practices. Occasional paper No 9. Overseas Development Institute, Regent's College, London (1993).

[9] Kiflu B and Berhanu K. Farmer Participatory Research: An Overview. Proceeding of client-Orient research evaluation workshop, 16-18 October 2001, Holetta Agricultural Research Center, Holetta, Ethiopia. EARO, Addis Ababa, Ethiopia, 2002, PP. 77-82.

[10] Asgelil D, Gemechu K, Hussien H, Fasil K. The Potential of Participatory Research in Ethiopia: Institutionalization of Farmers Participatory Research in South Nations-Nationalities and Peoples` regional State. In: Telahun, A, Habtu, A, Atroud, A. (eds.). Participatory research in action: Ethiopian experience. EARO and AHI, Addis Ababa Ethiopia, 2002, pp. 45-57.

[11] CSA, The Federal Democratic Republic of Ethiopia, Central Statistical Agency, Agricultural Sample Survey, 2008, Volume I, Report On Area And Production Of Crops, (Private Peasant Holdings, Meher Season), Addis Ababa, June, 2008, Statistical Bulletin 417, 2008.

[12] Chimdo A, Adane D, Habtamu A, Endeshaw H. Enhancing Innovation through Farmers Research Group (FRG): Basic Concept and Experience in Other Countries. Proceeding of workshop 20-21 October 2004, JARC, Jimma, 2005, pp. 29-40.

[13] Sanginga PC, Tumwine J, Lilja, N. Patterns of participation in farmers` research group: Lessons from the highlands of southwestern Uganda. Agriculture and Human value. Uganda 2006.

[14] Critchley W. Promoting farmer innovation, harnessing local environmental knowledge in East Africa, workshop report no 2, UNDP - office to combat desertification and drought (UNSO/SEED/BDP), and SIDA's regional land management unit (RELMA), 1999.

[15] Freeman HA. Comparison of farmer-participatory research methodologies: case studies in Malawi and Zimbabwe. Working Paper Series No.10. Socioeconomics and Policy Program, International Crops Research Institute for the Semi-Arid Tropics. Nairobi, Kenya. 2001, pp. 28-35.

[16] Agajie T, Chilot Y, Taye B. Experiences of participatory research in the national agricultural research system of Ethiopia. In: Gemechu K, Yohannes G, Kiflu B, Kiflu B, Chilot Y, Asgelil D. (eds) 
Towareds Farmers` Participatory Research: Attempts and achievements in the Central Highlands of Ethiopia. Proceedings of ClientOrient Research Evaluation Workshop, 16-18 October 2001, Holeta Agricultural Research Center, Holetta, Ethiopia, 2002, pp. 12-26.

[17] IFPRI Seed System potential in Ethiopia, Constraints and opportunities for enhancing production, international food policy research, working paper, July 2010, 2010.

[18] Adane H, Meuwissen M, Agajie T, et al. Analysis of Seed Potato Systems in Ethiopia, American Journal of Potato Research, (2010)
87:537-552, DOI 10.1007/s12230-010-9164-1, Published online: 11 September 2010 ,

[19] Bekele K, Eshetu B. Potato disease management. In Root and tuber crops: The untapped resources, ed. Gebremedhin W, Endale G. Lemaga B. Addis Ababa: Ethiopian Institute of Agricultural Research, 2008, 79-96.

[20] Ejigu J. Farmer participatory research: experience of FARM Africa. Proceeding of workshop 20-21 October 2004, JARC, Jimma, 2005, pp. 41-52.

(C) Beraka and Abrha; Licensee Bentham Open.

This is an open access article licensed under the terms of the Creative Commons Attribution Non-Commercial License (http://creativecommons.org/licenses/by-nc/3.0/) which permits unrestricted, non-commercial use, distribution and reproduction in any medium, provided the work is properly cited. 